International Journal of Pharmaceutical and Life Sciences

ISSN 2305-0330

Volume 1, Issue 2, Serial 4: September 2012

\title{
THROMBOLYTIC \& CYTO-TOXIC PROPERTY OF ETHANOL, ACETONE \& DM WATER EXTRACT OF Tamarindus indica Linn. FRUITS PULP: \\ AN IN-VITRO EVALUATION
}

S. M. Moazzem Hossen ${ }^{* 1}$, Mohammad Enamul Hoque ${ }^{1}$, Md. Raihan sarkar ${ }^{2}$, Md. Shahidul Islam${ }^{1}$, Md. Sahamir Hossain ${ }^{1}$, Md. Mahbub Rashid ${ }^{1}$

1. Department of pharmacy, University of Science and Technology Chittagong

2. Department of Pharmacy, Southeast University, Dhaka, Bangladesh

\begin{abstract}
In-vitro evaluation of Thrombolytic and cyto-toxic property of Tamarindus indica Linn. fruits pulp in three different extract, Ethanol, Acetone and DM water extract is the aim of the research work. The methods adopted in the investigation are Brine shrimp Lethality Bioassay for cytotoxic activity determination and in-vitro Thrombolytic study for clotlysis activity determination. The findings of the investigation were significant and found that Tamarindus indica Linn. fruits pulp have potential thrombolytic and cytotoxic activity. Tamarindus indica Linn. fruits pulp may be a new and potential source of thrombolytic and cytotoxic agent.
\end{abstract}

Key words: Tamarindus indica Linn., Pulp, Thrombolytic Activity, Cyto-toxic Activity, Brine Shrimp, Bioassay.

Corresponding Author:

S. M. Moazzem Hossen

Lecturer, Department of Pharmacy, University of Science \& Technology Chittagong (USTC).

Cell Phone: +880-01816071263, E-mail: hossen.Pharmacy@hotmail.com 


\section{International Journal of Pharmaceutical and Life Sciences}

ISSN 2305-0330

Volume 1, Issue 2, Serial 4: September 2012

\section{Introduction}

Tamarindus indica Linn., (Tamarind), family, Leguminosae, is one such widely used medicinal plant. It is found in virtually all tropical climatic regions, from India, Bangladesh through Africa to the Caribbean and South America and up to Southern Florida. Its uses are as varied as the cultures that use it. It is often more difficult to determine which use is more important, as food and beverage [1, 2] or as folklore medicine [2,3]. In the West African sub-region, including Nigeria, it is widely used as both food and medicine. The pulp has been documented in both the British and American pharmacopoeias as anti-pyretic, antiscorbutic, laxative, carminative and remedy for biliousness and bile disorder [1-5] and the leaves have antihelmintic and vermifuge properties, destroying intestinal parasites [5]. The work reported here was carried out to validate the medicinal use of this plant in Northern Nigerian folklore.

\section{Materials \& Methods}

\section{Identification and Collection}

Using standard taxonomical methods, supplied by the Bangladesh Forest Research Institute (BFRI), Chittagong, identified the plant's fruits. The fruits of the plant Tamarindus indica Linn. were collected from Baluchora, Chittagong on July 2011 and was identified by a Taxonomist of Bangladesh National Herbarium $(\mathrm{BNH})$. They were then separated \& cleaned from impurities. The fruits of the plant were air dried properly. After complete drying, the samples were ground 
into coarse powder with the help of a mechanical grinder and the powder was stored in a suitable container for extraction process.

\section{Preparation of the Plant Extract}

The powdered material was successively extracted with ethanol, acetone and DM water by using cold extraction process [6]. At first $250 \mathrm{gm}$ of dried powder was taken in an aspirator $(5 \mathrm{~L})$. Before placing powders into the aspirator, the jar was washed properly and dried. Then $750 \mathrm{ml}$ of solvent ethanol was added gradually. The time duration was of 21 days at room temperature with occasional shaking and stirring for each successive extraction. It was then filtered through a fresh cotton plug and finally with a Whatmann Filter paper no. 1. In the same way the powdered material was extracted with acetone. Finally this three extracts were concentrated by rotary evaporator in dry \& clean air.

\section{In Vitro Thrombolytic Study}

Experiments for clotlysis were carried as reported earlier [7]. Venous blood drawn from healthy volunteers was transferred in different pre-weighed sterile Eppendorf tube $(500 \mu \mathrm{l} / \mathrm{tube})$ and incubated at $37^{\circ} \mathrm{C}$ for 45 minutes. After clot formation, serum was completely removed (aspirated out without disturbing the clot formed). Each tube having clot was again weighed to determine the clot weight $($ Clot weight $=$ weight of clot containing tube - weight of tube alone). Each Eppendorf tube containing clot was properly labeled and $100 \mu \mathrm{l}$ of plant extract was added to the tubes. All the tubes were then incubated at $37^{\circ} \mathrm{C}$ for 90 minutes 
International Journal of Pharmaceutical and Life Sciences ISSN 2305-0330

Volume 1, Issue 2, Serial 4: September 2012

and observed for clotlysis. After incubation, fluid obtained was removed and tubes were again weighed to observe the difference in weight after clot disruption. Difference obtained in weight taken before and after clotlysis was expressed as percentage of clotlysis. Streptokinase and water were used as a positive and negative (non thrombolytic) control respectively. The experiment was repeated several times with the blood samples of different volunteers.

$\%$ clot lysis $=($ Weight of the lysis clot $/$ Weight of clot before lysis $) \times 100$

\section{Streptokinase (SK) Solution Preparation}

To the commercially available lyophilized SK vial (Polamin Werk GmbH, Herdecke, Germany) of 15,00,000 I.U., $5 \mathrm{ml}$ sterile distilled water was added and mixed properly. This suspension was used as a stock from which $100 \mu \mathrm{l}(30,000$ I.U) was used for in vitro thrombolysis.

\section{Brine Shrimp Lethality Bioassay Cytotoxic activity [8, 9]}

Cytotoxicity of the extract was tested by using brine shrimp lethality bioassay. Test solution ( Ethanol, Acetone and DM water extract in DMSO) of different concentrations as $5,15,30,60,120,240,300,350,400,450,500,550,600,650$ and $700 \mu \mathrm{g} / \mathrm{ml}$ was applied to the test tubes containing hatched brine shrimp nauplii in sea water followed by counting the survived naupli after $24 \mathrm{~h}$. 


\section{International Journal of Pharmaceutical and Life Sciences}

ISSN 2305-0330

Volume 1, Issue 2, Serial 4: September 2012

\section{Hatching of Brine Shrimp}

For the preparation of sea water $38 \mathrm{gm}$ of sodium chloride was weighed, dissolved in distilled water to make 1 liter solution and then filtered off to be a clear solution. This simulated sea water was used for a hatching of brine shrimp. The shrimp were allowed for two days to hatch and mature as nauplii (larvae).

\section{Preparation of Sample}

In a small beaker, measured amount of the sample was accurately weighed and dissolved in DMSO (Dimethylsulfoxide) to give a final concentration of $10 \mathrm{mg} / \mathrm{ml}$ $(10 \mu \mathrm{g} / \mu \mathrm{l})$

\section{Application of Test Sample to the Test Tube Containing Brine Shrimp Nauplii}

15test tubes for the sample were taken where each contained $5 \mathrm{ml}$ of seawater and 10 nauplii. These test tubes were marked from 1 to 15 for the sample. To test tubes different concentration of sample solution were added to give the concentration of $5 \mu \mathrm{g} / \mathrm{ml}, 15 \mu \mathrm{g} / \mathrm{ml}, 30 \mu \mathrm{g} / \mathrm{ml}, 60 \mu \mathrm{g} / \mathrm{ml}, 120 \mu \mathrm{g} / \mathrm{ml}, 240 \mu \mathrm{g} / \mathrm{ml}$, $300 \mu \mathrm{g} / \mathrm{ml}, 350 \mu \mathrm{g} / \mathrm{ml}, 400 \mu \mathrm{g} / \mathrm{ml}, 450 \mu \mathrm{g} / \mathrm{ml}, 500 \mu \mathrm{g} / \mathrm{ml}, 550 \mu \mathrm{g} / \mathrm{ml}, 600 \mu \mathrm{g} / \mathrm{ml}$, $650 \mu \mathrm{g} / \mathrm{ml}$ and $700 \mu \mathrm{g} / \mathrm{ml}$ of the sample respectively. Then the samples were subjected to brine shrimp lethality bioassay. 


\section{Preparation of Control Solution}

Two control groups were used in Cytotoxicity study, to validate the test method and results obtained due to the activity of the test agent.

\section{Negative Control Test:}

In this case, only $30 \mu \mathrm{l}$ DMSO was added in $5 \mathrm{ml}$ sea water containing 10 Nauplii. No extract was added to prepare control solution.

\section{Positive Control Test:}

Measured amount of the Vincristine Sulphate (VINCRIRST ${ }^{\circledR}$, Techno Drugs Ltd., Bangladesh) was dissolved in DMSO to get an initial concentration of $3125 \mu \mathrm{g} / \mathrm{ml}$. 9 test tubes for the standard sample were taken where each contained $5 \mathrm{ml}$ of seawater and 10 nauplii. These test tubes were marked from 1 to 9. Necessary dilution of Vincristine Sulphate solution was done to get required concentration of the standard sample solution respectively. Standard sample solution concentration were $1.25 \mu \mathrm{g} / \mathrm{ml}, 2.5 \mu \mathrm{g} / \mathrm{ml}, 5 \mu \mathrm{g} / \mathrm{ml}, 10 \mu \mathrm{g} / \mathrm{ml}, 15 \mu \mathrm{g} / \mathrm{ml}$, $20 \mu \mathrm{g} / \mathrm{ml}, 25 \mu \mathrm{g} / \mathrm{ml}, 30 \mu \mathrm{g} / \mathrm{ml}, 35 \mu \mathrm{g} / \mathrm{ml}, 40 \mu \mathrm{g} / \mathrm{ml}, 45 \mu \mathrm{g} / \mathrm{ml}, 50 \mu \mathrm{g} / \mathrm{ml}, 55 \mu \mathrm{g} / \mathrm{ml}$, $60 \mu \mathrm{g} / \mathrm{ml}, 65 \mu \mathrm{g} / \mathrm{ml}, 70 \mu \mathrm{g} / \mathrm{ml}$ and $75 \mu \mathrm{g} / \mathrm{ml}$.

\section{Result}

\section{Thrombolytic Study}

Thrombolytic study results are significant and summarized in table 1 and figure 1 . 


\section{International Journal of Pharmaceutical and Life Sciences}

ISSN 2305-0330

Volume 1, Issue 2, Serial 4: September 2012

Table 1: Thrombolytic effect of Tamarindus indica Linn. fruits pulp samples

\begin{tabular}{|ll|}
\hline Sample & $\%$ Clotlysis \\
Blank (DM Water) & 2.1 \\
Standard (streptokinase) & 86.3 \\
Ethanol + pulp extract & 57 \\
Acetone + pulp extract & 52.9 \\
DM water + pulp extract & 55.3 \\
\hline
\end{tabular}

Figure 1: Thrombolytic activity comparison among different sample Tamarindus indica Linn fruits pulp. (Sample $=$ Ethanol fruits pulp Extract, Acetone fruits pulp Extract, Ethanol fruits pulp Extract.) Standard $=$ Streptokinase

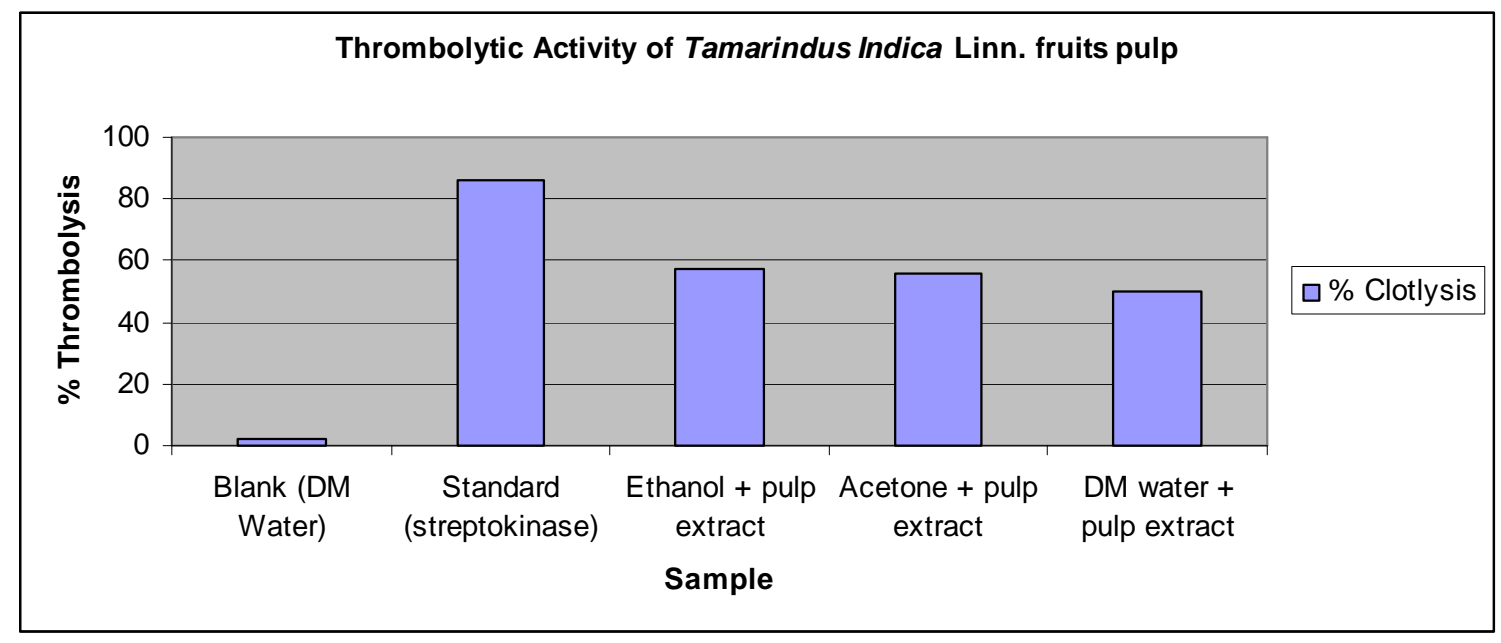

\section{Brine Shrimp Lethality Bioassay}

Brine Shrimp Lethality Bio-assay of ethanol pulp extract of Tamarindus indica Linn. was performed and results are summarized in table 2. Similarly Brine shrimp lethality bioassays were performed for Acetone Pulp extract and DM water Pulp extract of Tamarindus indica Linn. $\mathrm{LC}_{50} \& \mathrm{LC}_{90}$ was determined from graph . All results are summarized in table 3 and figure 2 . 
International Journal of Pharmaceutical and Life Sciences ISSN 2305-0330

Volume 1, Issue 2, Serial 4: September 2012

Table 2: Brine Shrimp Lethality Bio-assay of ethanol pulp extract

\begin{tabular}{|c|c|c|c|c|c|c|c|}
\hline $\begin{array}{l}\text { Test } \\
\text { sample }\end{array}$ & $\begin{array}{l}\text { Conc. } \\
(\mu \mathrm{g} / \mathrm{ml})\end{array}$ & $\begin{array}{l}\text { Log } \\
\text { (Conc.) }\end{array}$ & $\begin{array}{l}\text { No. of } \\
\text { Nauplii } \\
\text { in each } \\
\text { tube. }\end{array}$ & $\begin{array}{l}\text { Avg. no. } \\
\text { of alive } \\
\text { shrimp }\end{array}$ & $\begin{array}{l}\% \\
\text { mortality }\end{array}$ & $\begin{array}{l}\mathrm{LC}_{50} \\
(\mu \mathrm{g} / \mathrm{ml})\end{array}$ & $\begin{array}{l}\mathrm{LC}_{90} \\
(\mu \mathrm{g} / \mathrm{ml})\end{array}$ \\
\hline \multirow{14}{*}{$\begin{array}{c}\text { Ethanol } \\
\text { pulp } \\
\text { Extract }\end{array}$} & 5 & 0.6989 & 10 & 10 & 00 & \multirow{14}{*}{282} & \multirow{14}{*}{501} \\
\hline & 15 & 1.176 & 10 & 10 & 00 & & \\
\hline & 30 & 1.477 & 10 & 10 & 10 & & \\
\hline & 60 & 1.778 & 10 & 9 & 10 & & \\
\hline & 120 & 2.079 & 10 & 8 & 20 & & \\
\hline & 240 & 2.380 & 10 & 6.5 & 35 & & \\
\hline & 300 & 2.477 & 10 & 4.5 & 55 & & \\
\hline & 350 & 2.544 & 10 & 3.5 & 65 & & \\
\hline & 400 & 2.602 & 10 & 2.5 & 75 & & \\
\hline & 450 & 2.653 & 10 & 2 & 80 & & \\
\hline & 500 & 2.698 & 10 & 1.5 & 85 & & \\
\hline & 550 & 2.74 & 10 & 1 & 90 & & \\
\hline & 600 & 2.778 & 10 & 0.5 & 95 & & \\
\hline & 650 & 2.812 & 10 & 0 & 100 & & \\
\hline
\end{tabular}


International Journal of Pharmaceutical and Life Sciences

ISSN 2305-0330

Volume 1, Issue 2, Serial 4: September 2012

Table 3: $\mathrm{LC}_{50}$ and $\mathrm{LC}_{90}$ of different samples

\begin{tabular}{|l|l|l|}
\hline Test sample & $\mathrm{LC}_{50}(\mu \mathrm{g} / \mathrm{ml})$ & $\mathrm{LC}_{90}(\mu \mathrm{g} / \mathrm{ml})$ \\
\hline Ethanol pulp Extract & 282 & 501 \\
\hline Acetone pulp extract & 316 & 524 \\
\hline DM water pulp extract & 331 & 562 \\
\hline Standard & 16 & 63 \\
\hline
\end{tabular}

Figure 2: Lethality Bio-assay result of Tamarindus indica Linn. fruit pulp extract sample

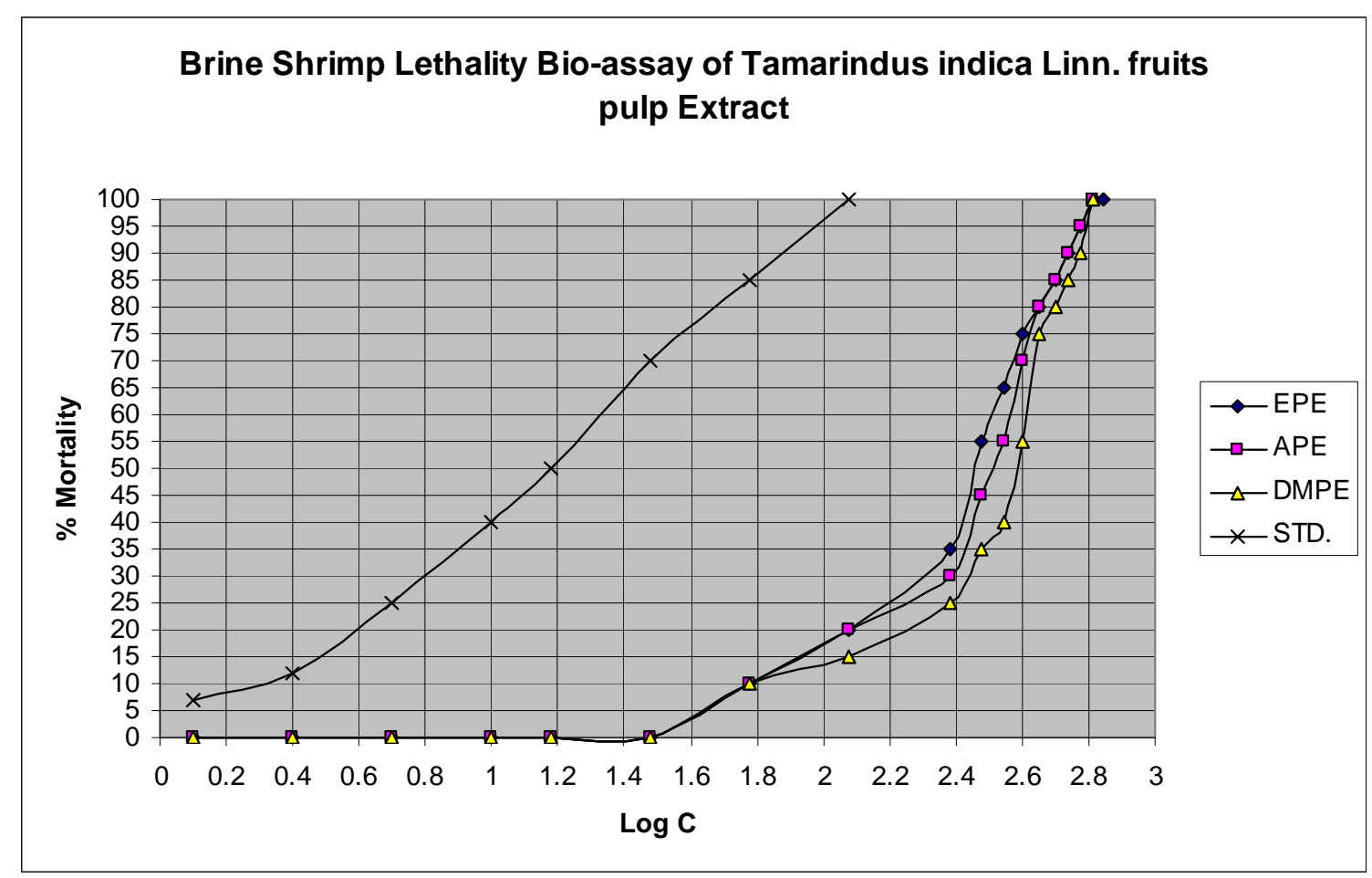

\section{Discursion}

The percentage of weight loss of clot after application of extract solution was taken as the functional indication of thrombolytic activity. The average value of percentage of weight loss was calculated and shown in the bellow data analysis. 
Results are summarized in table 1 and figure 1. Tamarindus indica Linn. fruits pulp has significant thrombolytic activity.

In brine shrimp lethality bioassay using brine shrimp Nauplii, the Ethanol, Acetone and DM water extract of Tamarindus indica Linn. fruits pulp showed positive result in comparison with the positive control Vincristine Sulphate \& that's why it can be assumed that extract is pharmacologically active. By plotting the $\log$ of concentration $(\log C)$ versus percent $(\%)$ mortality for all test samples showed an approximate linear correlation. From the graph, the median lethal concentration ( $\mathrm{LC}_{50}$, the concentration at which $50 \%$ mortality of brine shrimp nauplii occurred) were determined and $\mathrm{LC}_{90}$ values were also determined to check the toxic level of the extract. The crude extract of Tamarindus indica Linn. fruit pulp showed significant cytotoxic activity against brine shrimp nauplii. $\mathrm{LC}_{50}$ and $\mathrm{LC}_{90}$ were determined and compared with standard. Ending of discursion we can say that Tamarindus indica Linn. fruits pulp may be a potential source of new chemical entity in cytotoxic agent.

\section{Conclusion}

The demonstration of cytotoxic activity and thrombolytic activity of Tamarindus indica Linn. fruits pulp extract may help to discover new chemical classes of cytotoxic and thrombolytic agent. This investigation has opened up the possibility of the use of this plant in drug development for human consumption possibly for 


\section{International Journal of Pharmaceutical and Life Sciences}

ISSN 2305-0330

Volume 1, Issue 2, Serial 4: September 2012

the treatment of thromboembolism and cancer. Further investigations for individual drug compound may open wider door new drug entity.

\section{Reference}

1. Anon, B. The Useful Plants of India; Publications \& Information Directorate, CSIR: New Delhi, India, 1986.

2. Morton, J. Tamarind. In Fruits of Warm Climates; Creative Resources Systems, Inc.: Santa Ana, CA, USA, 1987; 115-121.

3. Pamploma-Roger, G.D. Encyclopaedia of Medicinal Plants; Education and Health Library: Madrid, Spain, 1999; Volume 2; 536.

4. Iwu, I.M. Handbook of African Medicinal Plants; CRC Press: Boca Raton, FL, USA, 1993.

5. Raimondi, L.; Lodovici, M.; Guglielmi, F.; Banchelli, G.; Ciuffi, M.; Boldrini, E.; Pirisino, R. The polysaccharide from Tamarindus indica (TSpolysaccharide) protects cultured corneal-derived cells (SIRC cells) from ultraviolet rays. J. Pharm. Pharmacol. 2003, 55; 333-338.

6. Trease G.E. and Evans W.C., Pharmacognosy, Baillier Tindall, London, 12th edition, 1983; 256-257.

7. Sweta Prasad, Rajpal Singh Kashyap, Jayant $Y$ Deopujari, Hemant J Purohit, Girdhar M Taori and Hatim F Daginawala. Effect of Fagonia Arabica (Dhamasa) on in vitro thrombolysis, BMC Complementary and Alternative Medicine 2007, 7:36 doi:10.1186/1472-6882-7-36. 


\section{International Journal of Pharmaceutical and Life Sciences}

ISSN 2305-0330

Volume 1, Issue 2, Serial 4: September 2012

8. Mayer, B.N., Ferrigni N.R., Putnam J.E., Jacobsen L.B., Nichols D.E. and Mclaughlin J.L. 1982. Brine shrimp: a convenient bioassay for active plant constituents. Plant Medica. 45; 31- 34.

9. Goldstein A.L. and Kalkan S.M., 1974. Principles of Drug Action, 2nd edition, Willy Biochemical Health Publications, 376-381. 